\title{
Reliability and Validity Studies of the Turkish Version of the Children's Attitudes toward the Environment Scale-Preschool Version (CATES-PV) and the Analysis of Children's Pro-environmental Behaviors According to Different Variables
}

\author{
Hülya Gülay \\ Department of Preschool Education, Faculty of Education, Pamukkale University \\ Kinikli Campus-Denizli, Turkey \\ Tel: 90-258-296-1124Ｅ-mail: hulya.gulay@gmail.com
}

Received: May 8, $2011 \quad$ Accepted: June 5, $2011 \quad$ Published: October 1, 2011

doi:10.5539/ass.v7n10p229

URL: http://dx.doi.org/10.5539/ass.v7n10p229

\begin{abstract}
In Turkey, the number of environmental education studies on young children is not sufficient. This is primarily due to the fact that scales for measuring the pro-environmental behaviors of young children are quite limited in number and are not common. This research has two aims which to carry out the reliability-validity studies of preschool environment scale, and to analyze the pro-environmental behaviors of 5-6 years old children with regard to different variables (age, gender, socio-economic level). The research included 171 children of 5-6 years of age receiving preschool education in the province of Denizli, Turkey. The Children's Attitudes Toward the Environment Scale-Preschool Version (CATES-PV) is a 15 -item scale that one can use to assess the degree to which children's attitudes are pro-environmental. Study results have indicated that the CATES-PV Turkish Version is a reliable and valid measurement tool. The scale may be used to determine the pro-environmental behaviors of 5-6 years old Turkish children. This study provides a significant contribution to the field for further studies to be conducted in Turkey on the pro-environmental behaviors of young children. It is observed that the pro-environmental behaviors of the children included in the research differ according to age and socio-economic level. No difference was found between pro-environmental behaviors of children in terms of the gender variable.
\end{abstract}

Keywords: CATES-PV, Pro-environmental behaviors, Scale reliability and validity, Preschool period

\section{Introduction}

Environmental problems have increased dramatically with factors such as population growth, urbanization, tourism and industrialization. For example, rapid population growth may increase consumption and environmental pollution. In touristic regions, natural vegetation of settlements may be damaged and the environmental pollution risk in the sea and on land tends to increase during tourism seasons. Rapid urbanization may also accelerate the extinction of green areas especially in developing countries (Soylu, 2009). Thus, international studies have been carried out in recent years for the protection of the environment (Bahk, 2011; Cao, Chen \& Zhu, 2010; Short, 2010). The most important measure to be taken against environment problems is environmental education (Davis, 1998). The preschool period ( $0-6$ years old) draws attention in terms of introducing children to the concept of environment and developing environmental awareness. In this period, children's curiosity about the environment is at the highest level (Özdemir \& Uzun, 2006). This mainly stems from the speed of growth in this age group. Due to this rapid growth, children learn many skills and behavior in a short time in the early years of life. Development also increases the interaction with the environment. For children, every factor in the environment is new, unknown, and therefore, interesting.

Children, in the early years of their lives, recognize the environment by playing games and through self-experience and the communication they establish with adults. Recognition in this context refers to learning new behaviors and skills during an interaction with the environment and associating these behaviors and skills with existing ones. Thus, children will both improve themselves and gain knowledge about the external world. Knowing the environment is important because it shapes development in a positive way. Children, who regularly 
interact with the environment, will know more about the external world and adapt better to living conditions. They will also have more self-confidence. These all will be reflected on their behaviors in positive terms.

In this recognition period, it is important that the education to be given to children is planned carefully to teach them concepts about the environment and to create environmental awareness. Providing small children with environmental knowledge and enabling them to develop behaviors and attitudes about the environment are necessary for the permanence of the given information (Russo, 2001). Furthermore, children today, especially those who live in big cities, are born into societies which struggle with environmental problems. Living conditions prevent them from interacting adequately with the natural environment (Davis, 1998). In Turkey, especially in metropolitan cities and the provinces which attract immigrants and experience urbanization, it is observed that natural life areas such as parks, forests and woods gradually decrease and that they are situated in remote locations away from cities and/or city centers. In recent years, especially in developed countries with education systems, more importance is attached on creating environmental awareness in young children. In USA, Korea and several European countries, environmental education starts between 3-6 years of age (Chu et al., 2007; Domka, 2004; Scott, 2007). Previous studies (Stoecklin, 2001; Witt \& Kimple, 2008) have demonstrated that environmental knowledge, behaviors and attitudes attained in preschool period have short and long term effects. Short term effects may be listed as follows: children, who gain knowledge about the environment through environmental education and who develop environmental awareness and sensitivity, also develop social adaptation skills and adapt better to their environment and society. Their curiosity about nature increases. Environmental education also reinforces their aesthetic perception and scientific perspective (Shin, 2008). In the long term, environmental awareness gained in early years continues in ensuing years; and negative behaviors developed against the environment are not easily corrected at an older age. (Scott, 2007; Wilson, 1996). The gradually increasing environmental problems and the effect of environmental education especially on preschool children justify the necessity of conducting projects and studies on environmental education for young children. In the century we live in, it is highly important to provide young children with environmental awareness and enable them to develop a perspective for protecting, loving and improving the environment. Pro-environmental behaviors are among effective factors in gaining the targeted environmental awareness. Pro-environmental behaviors are defined as "behaviors that change the availability of materials or energy from the environment or alter the structure and dynamics of ecosystems or the biosphere positively" (Stern, 2000). Pro-environmental behavior is voluntary behavior required to develop environmentally friendly behavior (Iwata, 2004; Joireman et al., 2001). Those that display pro-environmental behavior are sensitive towards social consequences caused by environmental constitutions. They are interested in the environmental issues that may arise from individual and social behaviors. They have a diligent approach towards practicing environmentally responsible behaviors in every area of their daily lives (Iwata, 2004; Siegfried, Tdeschi, \& Cann, 1982). Pro-environmental behaviors are also classified under prosocial behaviors. Prosocial behavior refers to voluntary behaviors that is intended for the benefit of others and shaped with emotional consistency and social competence (Hawley, 2002; Hay \& Pawlby, 2003). Prosocial and pro-environmental behaviors are voluntary behaviors exhibited without any self-interest. In this respect, prosocial behaviors, which are shaped with intentions of improving one's own as well as other people's situation and with empathizing skills, will be also effective on several attitudes and skills on environmental awareness such as protecting animals and maintaining environmental purity. For example, someone who empathizes with animals in the street is likely to ease their lives by providing them with food and water. Similarly, someone who is aware that wastes dumped in the sea will harm sea creatures will not throw his/her thrash into the sea.

Therefore, supporting the social developments of children will provide a basis for the development of positive attitudes towards the environment. The early years of life are extremely important in learning about this type of behavior. Hence, the objectives of training programs include providing knowledge and raising awareness about the environment in young children, and increasing their sensitivity towards the environment. From this point of view, analysis of the pro-environmental behaviors of preschool children will reveal the development process of children's environmental behaviors, attitudes and skills. Accordingly, it will be possible to determine which and how variables affect the development of pro-environmental behaviors in children, and establish the conditions that facilitate this learning process in children. Thereby, environmental education programs may be prepared by a child-centered approach focusing on developmental characteristics.

There are some variables that affect small children's environmental behaviors. These variables include gender, age, family variables, socio-economic level, place of residence, and culture. Grodzinska-Jurczak, Stepska, Niezsporek and Bryda (2006), in their study conducted with 674 children aging 6 years old and their families, established that children's environmental behaviors can vary depending on their place of residence (village, city). 
This result has been concluded considering that children living in villages spend more time in nature compared to children living in cities, and they interact more with nature due to their living habits such as riding bicycles and walking instead of driving a car. It was also determined that children are affected by their parents' behaviors especially in the matter of energy saving. Dolnicar (2010) reported that pro-environmental behaviors (e.g., turning off the faucet while washing hands, switching unnecessary lights off, not throwing rubbish on the street, not hurting animals, enabling recycling, etc.) are closely associated with age, income and education level. It is noted that these behaviors show an increase with the increase in age, education and income level. Barr and Gill (2007) stated that positive environmental behaviors in children are substantially affected by social and environmental variables. Among these variables, socio-economic level, age, environmental knowledge level and social relationships play an important role in attaining positive environmental behaviors.

Environment scales prepared for preschool children in Turkey are inadequate. The measurement tools used in environmental scales generally consist of questionnaires prepared for the specified research topic. These studies were carried out with primary school children on the environment tend to show an increase, there are no sufficient studies on preschool children (Akçay, 2006; Yağlıkara, 2006). In the Preschool Education Program applied in preschool education institutions affiliated with the Ministry of National Education in Turkey; environmental scope, objective, issues and concepts are not given sufficient place (Gülay \& Ekici, 2010). This deficiency stems from the inadequate number and lesser availability of measurement tools on the subject. Thus, researches on the subject remain to be limited and insufficient. New research needs to be conducted on the environmental perceptions, attitudes and behaviors of young children. Measurements tools, which will reveal the pro-environmental behaviors of preschool children, will also support related studies to be conducted in Turkey. Measurement tools will allow researchers to assess children's pro-environmental behaviors in terms of different variables. It will be possible to determine the efficacy of the prepared environmental education programs by these measurement tools. In this respect, the present research has two objectives: to carry out the reliability-validity studies of preschool environment scale, and to analyze the pro-environmental behaviors of 5-6 years old children with regard to different variables (age, gender, socio-economic level).

\section{Method}

In the research, a scale adaptation study was performed in order to determine the reliability and validity of the Turkish version of CATES-PV (The Children's Attitudes toward the Environment Scale-Preschool Version).

\subsection{Participants}

The research included 171 children of 5-6 years of age receiving preschool education in the province of Denizli, Turkey. Seventy-nine of the children were girls $(46.2 \%)$ and 92 of them were boys $(53.8 \%)$. The age average was 5 years, 6 months, 11 days (not less than 5 years, 1 month, 1 day; not more than 6 years, 8 months, 26 days). Children were selected by random sampling method. A list was made of the primary school kindergartens, located in central Denizli and affiliated to the Ministry of Education, attended by children, whose families were low, middle and high socio-economic levels. Permission was requested from the schools and families of the children attending the six kindergartens on list, chosen by draft. Occupations and income levels of children's parents were taken as a basis for the variable of socio-economic level included in the research. Information on occupations and income levels were obtained from personal information forms and school directors. In line with this information, a socio-economic scale was established. Unemployed and worker fathers (had carrier, waiter, dustman etc.) and housewife mothers constituted the low socio-economic level in the research. The mean monthly income of the low socio-economic level is 684.6 US\$. The middle socio-economic level consisted of parents who were civil servants with a mean monthly income of 1.506 US\$. The parents constituting the high socio-economic level were self-employed and had a mean monthly income of 2.532 US\$.

\subsection{Measurements}

2.2.1 CATES-PV (The Children's Attitudes Toward the Environment Scale-Preschool Version): The Children's Attitudes toward the Environment Scale-Preschool Version (CATES-PV) was derived from the Children's Attitudes toward the Environment Scale for School-Age Children (CATES). In 1996, Musser and Malkus developed the Children's Attitudes toward the Environment Scale for School-Age Children (CATES) for primary students. The CATES is a 25 -item scale that one can use to assess the degree to which children's attitudes are pro-environmental (Musser \& Malkus, 1996). In 1999, Musser and Diamond developed The Children's Attitudes toward the Environment Scale-Preschool Version (CATES-PV) for preschool children. In the CATES-PV, 15 of the 25 questions from the Children's Attitudes toward the Environment Scale for School-Age Children (CATES) are used. Musser and Diamond decided that 10 of the 25 items in the Children's Attitudes toward the Environment Scale for School-Age Children (CATES) was inappropriate for young children and established the 
CATES-PV with the 15 remaining items (Musser \& Diamond, 1999). Listed below are some of the items of the scale:

Turning water off while brushing teeth

Recycling things

Wild animals need protection

Turning off the lights (Musser \& Diamond, 1999).

For each item on the CATES-PV, children are presented with a line drawing depicting a specific environmental issue, and the associated item is read to them. As with the CATES, children must choose behaviors which child or children they are most like. They then indicate, by pointing to a large or small circle, whether they are a lot or just a little like that child or children. Every item on the scale is scored between 1-4 score. In this measurement tool without a sub-scale, total scores are calculated. The highest and lowest scores to be obtained from the scale are 60 and 15, respectively. Total score obtained from the scale indicates the high level of pro-environmental behaviors. The scale is applied to children individually. CATES-PV is a scale developed for children between 4-6 years of age (Musser \& Diamond, 1999). However, in this research, reliability-validity studies were performed for 5-6 years old children. During the translation study, it was stated in the learned opinion of five academics specialized in preschool education and environmental education that the scale was not appropriate for four-year old children in Turkey. In addition, sample applications performed in 10 children in 4 years of age group revealed results parallel to the learned opinion, and it was observed that 4-year old children had difficulties in understanding the scale and answering the questions.

\subsection{Procedure}

2.3.1 Translation studies of the Turkish Version of CATES-PV: Scale items were translated into Turkish by 5 academics working on the subject. The translations were brought together and finalized. The final version of the translation was later translated back into English by a native-speaker academic who had been living in Turkey for a long period of time. After the back translation was completed, the two English forms were compared. The aim of this comparison was to check the accuracy and completeness of the translation from English to Turkish. Except a few minor differences which did not alter the original meanings, no difference was found between the two forms. The pictures of the scale items were drawn by the senior students of the Painting Teaching program. The learned opinion of a group of 6 specialists including academics and preschool education teachers was received for the compliance between the items and the pictures drawn. The pictures were finalized in line with the learned opinions.

2.3.2 Reliability studies of the Turkish version of CATES-PV: The arithmetic mean and standard deviations were calculated for the items whose scale was formed for the reliability of the CATES-PV Turkish Version. The internal consistency coefficient (Cronbach's Alpha) of the scale items was calculated. As the third stage of reliability studies, item analysis procedures were performed on the basis of item-total, item-remainder and item-discrimination values. In the final stage, test-retest technique was used to test the scale's invariance against time for 5-6 years old children. Therefore, the scale was applied once in 2 weeks to a group of 30 children selected randomly from the study group, and the relationship between two applications was analyzed by Pearson Product-Moment Correlation Coefficient technique.

2.3.3 Validity studies of the Turkish Version of CATES-PV: Learned opinion was consulted for the validity studies of the scale. Five academics with at least 10 years of experience and specialized in preschool education and environmental education assessed the scale in terms of appropriateness to the age group, consistency among the items, and appropriateness of the items to the Turkish culture and language. All leaned opinions agreed that the scale was capable of measuring the targeted behaviors in 5-6 years old children. Criterion validity of the scale could not be carried out due to the lack of such a scale of CATES-PV in Turkey designed for preschool children. T-test was applied to determine the item-discrimination power of the scale. The data obtained from the research were analyzed the SPSS 13.0 packet program.

One Way Analysis of Variance (ANOVA) technique was used to assess the pro-environmental behaviors of 5-6 years old children with regard to the variables of gender, age and socio-economic level. Scheffe Test among post-hoc techniques was applied to determine the level to which the observed difference in the variable of socio-economic level belonged. 


\section{Results}

In line with the primary objective of the research, findings of the reliability studies of CATES-PV Turkish Version are presented below:

\subsection{CATES-PV (The Children's Attitudes toward the Environment Scale - Preschool Version) Turkish Version's reliability}

Table 1 illustrates the arithmetic means and standard deviations of each item in the scale. Arithmetic means vary between 3.4327 and 3.8480. Standard deviations vary between .44752 and 1.00580.

The relationship between the items comprising the internal reliability of the scale was calculated by Cronbach's Alpha technique and this relationship was accepted as adequate (Cronbach's Alpha: .72, p <.001) (Table 2). Internal consistency coefficient of the original version of the scale is .68. Based on this result, the Turkish form of the scale was assumed to have internal reliability for 5-6 years old children.

All items of CATES-PV Turkish Version were found to be statistically significant on a level of .001 in terms of both item-total and item-remainder. According to the results, all the items of the scale were understood to be reliable, and therefore it was decided to include them all in the scale (Table 3).

As shown in Table 4, related coefficient is .950 depending on the application of CATES-PV Turkish Version twice with two week interval. A statistically significant relationship at a level of .001 was found between two measurements. The obtained result indicates that the scale has reliability on the basis of continuity (Table 4).

\subsection{Validity of CATES-PV (The Children's Attitudes toward the Environment Scale-Preschool Version) Turkish} Version

Learned opinion was sought in the content validity study of CATES-PV Turkish Version. The opinions of 3 academics specialized in primary school education and 3 preschool teachers with ten years of experience were consulted. Internal consistency studies included in the reliability section of the findings demonstrated that all scale items measured the intended qualification and structure. These results provided a proof on the content validity of the scale.

As illustrated in Table 5, according to the results of the t-test analysis on the item-discrimination power, each item of CATES-PV Turkish Version shows a statistically significant difference at a level of .001. This result establishes the item-discrimination power of the scale items.

\subsection{Assessment of the pro-environmental behaviors of 5-6 years old children with respect to various variables}

As demonstrated in Table 6 and 7, CATES-PV Turkish Version scores of 5-6 years old children revealed no significant difference according to gender $[\mathrm{F}(1,170)=1.829 ; \mathrm{p}>.001]$. This result shows that children's pro-environmental behaviors did not vary according to gender.

Tables 8 and 9 show that CATES-PV Turkish Version scores of 5-6 years old children differed significantly according to age $[\mathrm{F}(1,170)=266.279 ; \mathrm{p}<.001]$. Arithmetic means of CATES-PV Turkish Version scores of 6

years old children $(\bar{\chi}=58.4545)$ were significantly higher than the arithmetic means of CATES-PV Turkish

Version scores of 5 years old children $(\bar{\chi}=51.0556)$.

As it can be seen in Tables 10 and 11, at the end of the one-way ANOVA about the CATES-PV Turkish Version scores according to the socio-economic levels of the families, significant difference $[F(2,170)=15.938 ; p$ $<.001]$ was observed among the Turkish language scores of the children according to the socio-economic levels of the families. Pro-environmental behaviors of the children differed significantly according to the socio-economic levels of the families. According to the results of the Scheffe test (Table 12) which was carried out in order to determine which group caused the difference in socio-economic level variable, CATES-PV Turkish Version scores of the children whose families were at high socio-economic level $(\bar{\chi}=57.9615)$ were 
significantly higher than the CATES-PV Turkish Version scores of the children whose families were at middle socio-economic level $(\bar{\chi}=55.3415)$ and low socio-economic level $(\bar{\chi}=53.5897)$.

\section{Discussion}

Study results have indicated that CATES-PV (The Children's Attitudes toward the Environment Scale-Preschool Version) Turkish Version is a reliable and valid measurement tool for the selected sample group. The scale may be used to determine the pro-environmental behaviors of 5-6 years old Turkish children. Environmental issues were included in the preschool curriculum because of its important role in environmental education, and, in time, the "Early childhood education for sustainability" concept formed as a result of these relevant studies. As well as helping the children's development, early childhood education, aims to bring up children that are sensitive, and show an interest in the environment, and are willing to take responsibility in related subjects (OECD, 2006). Today, successful education is related with sustainable development. It is obvious from studied carried out in various countries (Forest School-UK, Green Preschool Award-Hong Kong; Starting Strong 2, Third teacher in Reggio Emilia classroom, We are Learning about the Soil with Tipitop and His Friends 1) that numerous approaches are available to create environmental awareness in small children (Borradaile 2006; Davis, 2009; Gülay, Yılmaz, Turan-Güllaç \& Önder, 2010; Lee, Jo \& Park 2007; OECD, 2006). The environmental training projects, activities, and different practices within the early childhood education programs support sustainable development as well as raising environmental awareness in children.

In a developing country like Turkey, environmental training practices for small children have gained momentum. However, all relevant studies are directed at primary school, high school, and university students (Atasoy, 2005; Budak, 2008; Işeri-Gökmen, 2008; Şüyün, 2010; Tecer, 2007). In general, the subjects addressed by environmental training studies for preschool children in Turkey are the views of preschool children and teachers on environmental issues, analyzing the effects of environmental training programs, how environmental issues are handled in training programs, and with what frequency (Akçay, 2006; Buhan, 2006; Çabuk, 2001; Gülay \& Ekici, 2010; Gülay et al., 2010; Haktanır \& Çabuk, 2000; Kesicioğlu \& Alisinanoğlu, 2009; Taşkın \& Şahin, 2008; Yağlıkara, 2006). There is no measurement tool including pro-environmental behaviour in any of the studies listed. Under these circumstances, owing to adapting the CATES-PV (The Children's Attitudes toward the Environment Scale-Preschool Version) to Turkish it is expected to increase and spread environmental training studies for preschool children. Studies improved with measurement tools will enrich the context of studies. Children will be made aware of environmental at an early age, and a foundation will be established for developing experimental studies and environmental training programmes.

It is observed that the pro-environmental behaviors of the children included in the research differ according to age and socio-economic level. It is also seen that pro-environmental behaviors increase depending on age. Learning in preschool period is fast enough to create significant differences in a single year (Gülay, 2010; Oktay, 2000). In the study conducted by Çabuk (2001) with 200 children of 3-6 years old, it was reported that children's awareness increased depending on age. Musser and Diamond (1999), within the scope of the reliability and validity studies of CATES-PV for preschool children, investigated the pro-environmental behaviors of the study group also with respect to age, and noted that these behaviors showed an increase with the increase in age.

Similarly, in terms of socio-economic level, higher level of pro-environmental behaviors was observed in children from families of higher socio-economic level. Pro-environmental behaviors at lower level were exhibited by children from families of lower socio-economic level. In the study carried out by Grodzinska-Jurczak, Stepska, Niezsporek and Bryda (2006), it was determined that environmental behaviors of 6 years old children did not differ according to socio-economic level, but according to their place of residence (village, city). Haktanır and Çabuk (2000), on the other hand, in their study conducted with 80 children in the age group of 3-6 years old, reported that the environmental perception of the children coming from families of upper socio-economic level was higher compared to children coming from families of lower socio-economic level. Morrone, Mancl and Carr (2001) also stated that children coming from low socio-economic level had less interest towards environmental problems compared to children coming from other socio-economic levels.

No difference was found between pro-environmental behaviors of children in terms of the gender variable. This finding demonstrates that there is no gender related difference in child education and child raising attitudes. Environmental education given in the family and in preschool education institutions does not differ according to the gender of children. It is an expected and desired result that the given education and the intended attitudes, behaviors and skills do not differ according to gender. Gender should not be a determining variable in 
environmental attitudes. Environment and all environment related concepts affect and concern both sexes to the same degree. It is possible to encounter other studies that also support the absence of gender difference in environmental researches conducted with preschool children (Çabuk, 2001; Musser \& Diamond, 1999). In parallel with these findings, Teodori and Luloff (2002) determined in their research that pro-environmental behaviors differ according to age, socio-economic level and education level, but not according to gender. As is seen, in the direction of second aim of the research, the findings obtained from the assessment of pro-environmental behaviors with respect to different variables show consistency with the results of other studies on the subject.

In Turkey, studies carried out with preschool children should become widespread. As mentioned above, a great part of the studies on the subject do not focus on determining pro-environmental behaviors. These studies may be conducted more easily and on a more common basis if the number of measurement tools for this subject of study is increased. In later studies, new reliability studies may be carried out regarding the CATES-PV Turkish version. In these studies, children's voices may be recorded during the use of the scale, and scoring may be reevaluated after the application. In addition, new measurement tools may be developed to put forth pro-environmental behavior in young children. It is important to increase the number of measurement tools in order to establish the development profile of children's environmental knowledge, behaviors and attitudes as well as to determine how children are affected by which factors. In this way, more realistic and need-oriented environmental education policies can be designed. The results of this research have designated age and socio-economic level as significant factors in the development of pro-environmental behaviors. Therefore, children at an early age should be given opportunities to interact with the environment in accordance with their rate of development. In this way, an important step will be taken in raising conscious generations who do not pollute the environment, who value recycling, respect other creatures' right to life, consider energy saving, and love and protect the environment. Applications of environmental education should address to a wide range of intended target group covering also the families of lower and middle socio-economic levels.

\section{References}

Akçay, İ. (2006). Environmental education for preschool students in different countries. Unpublished master thesis. Bursa: Uludağ University, Turkey.

Atasoy, E. (2005). Education for environment: A Study for primary students environmental attitude and Environmental Knowledge. Unpublished doctoral dissertation. Bursa: Uludağ University, Turkey.

Bahk, C. M. (2011). Environmental education through narrative films: Impact of medicine man on attitudes toward forest preservation. The Journal of Environmental Education, 42(1), pp.1-13. http://dx.doi.org/10.1080/00958960903479811

Barr, S. \& Gill A. W. (2007). A Conceptual framework for understanding and analyzing attitudes towards environmental behaviour. Geografiska Annaler Series B: Human Geography, pp.361-379. http://dx.doi.org/10.1111/j.1468-0467.2007.00266.x

Borradaile, L. (2006). Forest School Scotland: An evaluation. Edinburgh: Forestry Commission Scotland.

Budak, B. (2008). The status of environmental education in primary school and application studies. Unpublished master thesis. Izmir: Ege University, Turkey.

Buhan, B. (2006). Investigation of preschool teacher's environmental awareness and environmental education in these schools. Unpublished master thesis. Istanbul: Marmara University, Turkey.

Cao, S., Chen, L. \& Zhu, Q. (2010). Remembering the ultimate goal of environmental protection: Including protection of impoverished citizens in China's environmental policy. AMBIO, 39, pp.439-442. http://dx.doi.org/10.1007/s13280-010-0043-2

Çabuk, B. (2001). Environmental awareness level of preschool children. Unpublished master thesis. Ankara: Ankara University, Turkey.

Chu, H. E., Lee, E. A., Ko, H. R., Shin, D. H., Lee, M. N., Min, B. M. \& Kang, K. H. (2007). Korean year 3 children's environmental literacy: A prerequisite for a Korean environmental education curriculum. International Journal of Science Education, 26(1), pp.731-746. http://dx.doi.org/10.1080/09500690600823532

Davis, J. (1998). Young children, environmental education and the future. Early Childhood Education Journal, 26(2), 117-123. http://dx.doi.org/10.1023/A:1022911631454 
Davis, J. (2009). Revealing the research 'hole' of early childhood education for sustainability: a preliminary survey of the literature. Environmental Education Research, 15(2), 227-241. http://dx.doi.org/10.1080/13504620802710607

Dolnicar, S. (2010). Identifying tourists with smaller environmental footprints. Journal of Sustainable Tourism, 18(6), pp.717-734. http://dx.doi.org/10.1080/09669581003668516

Domka, D. (2004). Environmental education at pre-school. International Research in Geographical and Environmental Education, 13(3), pp.258-263. http://dx.doi.org/10.1080/10382040408668520

Grodzinska-Jurczak, M., Stepska, A., Niezsporek, K. \& Bryda, G. (2006). Perception of environmental problems among pre-school children in Poland. International Research in Geographical and Environmental Education, 15(1), pp.62-76. http://dx.doi.org/10.2167/irgee187.0

Gülay, H. (2010). Peer relationships in preschool period. Ankara: PegemA Publishing.

Gülay, H. \& Ekici, G. (2010). The Analysis of MNE Pre-School Education Programme in the sense of environmental education. Journal of Turkish Science Education, 7(1), pp.74-84.

Gülay, H., Yılmaz, Ş., Turan-Güllaç, E. \& Önder, A. (2010). The Effect of soil education project on pre-school children. Educational Research and Reviews, 5(11), pp.703-711.

Haktanır, G. \& Çabuk, B. (2000). Environmental perception in preschool children, IV. Science and Training Convention Report and Poster Book. 6-8 September 2000. Department of Education at Hacettepe University. Beytepe Ankara, p.21.

Hawley, P. H. (2002). Social dominance and prosocial and coercive strategies of resource control in preschoolers. International Journal of Behavioral Development, 26(2), pp.167-176. http://dx.doi.org/10.1080/01650250042000726

Hay, D. F. \& Pawlby, S. (2003). Prosocial development in relation to children's and mothers' psychological problems. Child Development, 74(5), pp.1314- 1327. http://dx.doi.org/10.1111/1467-8624.00609

İşeri-Gökmen, S. (2008). Effects of problem based learning on students' environmental attıtude through local vs. non local environmental problems. Unpublished master thesis. Ankara: Middle East Tecnical University, Turkey.

Iwata, O. (2004). Some Psychological Correlates of Environmentally Responsible Behavior. Social Behavior and Personality, 32(8), pp.703-714. http://dx.doi.org/10.2224/sbp.2004.32.8.703

Joireman, J. A., Lasane, T. P., Bennett, J., Richards, D. \& Solaimani, S. (2001). Integrating social value orientation and the consideration of future consequences within the extended norm activation model of proenvironmental behaviour. British Journal of Social Psychology, 40, pp.133-155. http://dx.doi.org/10.1348/014466601164731

Kesicioğlu O. S. \& Alisinanoğlu, F. (2009). The analysis of children's attitude against the environment in the views of various variables. Ahi Evran University Faculty of Education Journal, 10(3), pp.37-48.

Lee, Y., Jo, H. \& Park, S. (2007). Exploring the contemporary position and outlook for eco-early childhood education through kindergarten teachers' awareness investigation of eco-early childhood education in South Korea. Paper presented at the 10th UNESCOAPEID International Conference, December 6-8, in Bangkok, Thailand.

Morrone, M., Manc1, K. \& Carr, K. (2001). Development of a metric to test group differences in ecological knowledge as one component of environmental literacy. The Journal of Environmental Education, 32, pp.33-42. http://dx.doi.org/10.1080/00958960109598661

Musser, L. M. \& Diamond, K. E. (1999). The children attitudes toward the envionment scale for preschool children. Journal of Environmental Education, 30(2), pp.155-162. http://dx.doi.org/10.1080/00958969909601867

Musser, L. M. \& Malkus, A. J. (1996). The children's attitudes toward the environmental scale. Journal of Environmental Education, 25(3), pp.22-26. http://dx.doi.org/10.1080/00958964.1994.9941954

OECD (2006). Starting strong 2: Early childhood education and care, Paris: Organization for Economic Co-operation and Development.

Oktay, A. (2000). Magic years of life. Istanbul: Epsilon Publications. 
Özdemir, O., \& Uzun, N. (2006). The effect of science and nature activities, carried out in accordance with the green class model, on the environmental perception of nursery students. Journal of Child Development and Education, 1(2), pp.12-20.

Russo, S. (2001). Promoting towards environmental education depends on early childhood education. Viewpoint. Australian Science Teachers Association, 17(4), pp.34-36.

Scott, S. A. (2007). Children's environmental knowing: a case study of children's experiences during an environmental education programme. Unpublished doctoral dissertation. Canada: The University of British Colombia.

Shin, K. H. (2008). Development of environental education in the Korean kindergarten context. Unpublished doctoral dissertation. Canada: University of Victoria.

Short, P. C. (2010). Responsible environmental action: Its role and status in environmental education and environmental quality. The Journal of Environmental Education, 41(1), pp.7-21. http://dx.doi.org/10.1080/00958960903206781

Siegfried, W. D., Tdeschi, R. G. \& Cann, A. (1982). The generalizability of attitudinal correlates of proenvironmental behavior, The Journal of Social Psychology, 118, pp.287-288. http://dx.doi.org/10.1080/00224545.1982.9922812

Soylu, H. (2009). The environmental problems caused by rapid urbanisation in Bingöl. Ankara University Institute of Social Science Journal, 13(1), 87-04.

Stern, P. C. (2000). Toward a coherent theory of environmentally significant behaviour. Journal of Social Issues, $56,407-424$.

Stoecklin, V. (2001). Developmentally appropriate gardening for young children. White Hutchinson Leisure and Learning Group (ERIC Document Reproduction Service No. ED346082).

Şüyün, B. (2010). Environmental consciousness and perceptions of secondary school students. Unpublished master thesis. Istanbul: Marmara University, Turkey.

Taşkın Ö. \& Şahin, B. (2008). Environmental concept and six years old preschool children. Pamukkale University Faculty of Education Journal, 1(23), pp.1-14.

Tecer, S. (2007). Education for environmental: a study on the level of determination of the primary students' environmental behaviour, knowledge, consciousness and active participitation in Balikesir City. Unpublished master thesis. Zonguldak: Zonguldak Karaelmas University, Turkey.

Teodori, G. L. \& Luloff, A. L. (2002). Position on Environmental Issues and Engagement in Proenvironmental Behaviors. Society \& Natural Resources, 15(6), pp.471-482. http://dx.doi.org/10.1080/08941920290069128

Wilson, R. A. (1996). Environmental education programs for preschool children. Journal of Environmental Education, 27(4), pp.28-33. http://dx.doi.org/10.1080/00958964.1996.9941473

Witt, S. D. \& Kimple, K. P. (2008). How does your garden grow ? Teaching preschool children about the environment. Early Child Development and Care, 178(1), 41-48. http://dx.doi.org/10.1080/03004430600601156

Yağlıkara, S. (2006). The teachers opinions about the effects of science and nature activities on the preschool children's acquisition of environmental awareness. Unpublished master thesis. Eskişehir: Anadolu University, Turkey. 
Table 1. Arithmetic means and standard deviation values of the items in CATES-PV Turkish Version

\begin{tabular}{llcc}
\hline \multicolumn{1}{c}{ Items } & $\mathrm{N}$ & $\bar{\chi}$ & $\mathrm{sd}$ \\
& & 3.5848 & .88564 \\
\hline 1 & 171 & 3.6667 & .66862 \\
2 & 171 & 3.6959 & .66060 \\
3 & 171 & 3.7544 & .57232 \\
4 & 171 & 3.7836 & .52577 \\
5 & 171 & 3.6257 & .79723 \\
6 & 171 & 3.8480 & .44752 \\
7 & 171 & 3.7018 & .66770 \\
8 & 171 & 3.4327 & 1.00580 \\
9 & 171 & 3.5380 & .75343 \\
10 & 171 & 3.7719 & .55363 \\
11 & 171 & 3.7544 & .56195 \\
12 & 171 & 3.8012 & .51586 \\
13 & 171 & 3.7251 & .66013 \\
14 & 171 & 3.6550 & .82833 \\
15 & 171 & \\
\hline
\end{tabular}

Table 2. Internal reliability (Cronbach's alpha) coefficient of CATES-PV Turkish Version

\begin{tabular}{cccc}
\hline & $\mathrm{N}$ & $\mathrm{r}$ & $\mathrm{p}$ \\
\hline Cronbach's Alpha & 171 & .72 & $\mathrm{p}<.001$ \\
\hline
\end{tabular}

Table 3. Results of the item analysis for CATES-PV Turkish Version

\begin{tabular}{lcccccccc}
\hline Items & $\mathrm{N}$ & $\begin{array}{c}\text { item-total } \\
\mathrm{r}\end{array}$ & $\mathrm{p}$ & $\begin{array}{c}\text { item-remainder } \\
\mathrm{r}\end{array}$ & $\mathrm{p}$ & $\begin{array}{c}\text { Discrimination } \\
\mathrm{t}\end{array}$ & $\mathrm{sd}$ & $\mathrm{p}$ \\
\hline 1 & & & & & & & \\
2 & 171 & .338 & $\mathrm{p}<.001$ & .708 & $\mathrm{p}<.001$ & -6.309 & 90 & $\mathrm{p}<.001$ \\
3 & 171 & .399 & $\mathrm{p}<.001$ & .701 & $\mathrm{p}<.001$ & -5.866 & 90 & $\mathrm{p}<.001$ \\
4 & 171 & .378 & $\mathrm{p}<.001$ & .703 & $\mathrm{p}<.001$ & -7.068 & 90 & $\mathrm{p}<.001$ \\
5 & 171 & .288 & $\mathrm{p}<.001$ & .712 & $\mathrm{p}<.001$ & -5.352 & 90 & $\mathrm{p}<.001$ \\
6 & 171 & .256 & $\mathrm{p}<.001$ & .716 & $\mathrm{p}<.001$ & 4.695 & 90 & $\mathrm{p}<.001$ \\
7 & 171 & .254 & $\mathrm{p}<.001$ & .701 & $\mathrm{p}<.001$ & -5.215 & 90 & $\mathrm{p}<.001$ \\
8 & 171 & .382 & $\mathrm{p}<.001$ & .720 & $\mathrm{p}<.001$ & -3.308 & 90 & $\mathrm{p}<.001$ \\
9 & 171 & .305 & $\mathrm{p}<.001$ & .702 & $\mathrm{p}<.001$ & -5.506 & 90 & $\mathrm{p}<.001$ \\
10 & 171 & .283 & $\mathrm{p}<.001$ & .716 & $\mathrm{p}<.001$ & -6.097 & 90 & $\mathrm{p}<.001$ \\
11 & 171 & .289 & $\mathrm{p}<.001$ & .714 & $\mathrm{p}<.001$ & -6.826 & 90 & $\mathrm{p}<.001$ \\
12 & 171 & .305 & $\mathrm{p}<.001$ & .711 & $\mathrm{p}<.001$ & -4.703 & 90 & $\mathrm{p}<.001$ \\
13 & 171 & .342 & $\mathrm{p}<.001$ & .708 & $\mathrm{p}<.001$ & -5.125 & 90 & $\mathrm{p}<.001$ \\
14 & 171 & .448 & $\mathrm{p}<.001$ & .695 & $\mathrm{p}<.001$ & -4.455 & 90 & $\mathrm{p}<.001$ \\
15 & 171 & .350 & $\mathrm{p}<.001$ & .706 & $\mathrm{p}<.001$ & -4.393 & 90 & $\mathrm{p}<.001$ \\
& & & & & & -5.051 & 90 & $\mathrm{p}<.001$ \\
\hline
\end{tabular}

Table 4. Results of test- retest reliability analysis of CATES-PV Turkish Version
CATES-PV Turkish Version's
$\mathrm{N}$
$\bar{\chi}$

$\mathrm{S} \quad \mathrm{r} \quad p$

\begin{tabular}{clllll}
\hline Pre Test & 30 & 55.7667 & 3.05900 & .950 & $\mathrm{p}<.001$ \\
Post Test & 30 & 55.8667 & 3.18112 & & \\
\hline
\end{tabular}


Table 5. Results of the t-test analysis performed for the item-discrimination power of CATES-PV Turkish Version

\begin{tabular}{|c|c|c|c|c|c|c|c|}
\hline Items & Discrimination & $\mathrm{N}$ & $\bar{\chi}$ & S & $\mathrm{t}$ & df & $p$ \\
\hline \multirow[t]{2}{*}{1} & Sub-group & 46 & 3.0000 & 1.07497 & -6.309 & 90 & $\mathrm{p}<.001$ \\
\hline & Upper-group & 46 & 4.0000 & .00000 & & & \\
\hline \multirow[t]{2}{*}{2} & Sub-group & 46 & 3.2609 & .85465 & -5.866 & 90 & $\mathrm{p}<.001$ \\
\hline & Upper-group & 46 & 4.0000 & .00000 & & & \\
\hline \multirow[t]{2}{*}{3} & Sub-group & 46 & 3.0435 & 91.788 & -7.068 & 90 & $\mathrm{p}<.001$ \\
\hline & Upper-group & 46 & 4.0000 & .00000 & & & \\
\hline \multirow[t]{2}{*}{4} & Sub-group & 46 & 3.5217 & .79885 & -5.352 & 90 & $\mathrm{p}<.001$ \\
\hline & Upper-group & 46 & 4.0000 & .00000 & & & \\
\hline \multirow[t]{2}{*}{5} & Sub-group & 46 & 3.5217 & .69087 & 4.695 & 90 & $\mathrm{p}<.001$ \\
\hline & Upper-group & 46 & 4.0000 & .00000 & & & \\
\hline \multirow[t]{2}{*}{6} & Sub-group & 46 & 3.1087 & 1.15909 & -5.215 & 90 & $\mathrm{p}<.001$ \\
\hline & Upper-group & 46 & 4.0000 & .00000 & & & \\
\hline \multirow[t]{2}{*}{7} & Sub-group & 46 & 3.7391 & .53478 & -3.308 & 90 & $\mathrm{p}<.001$ \\
\hline & Upper-group & 46 & 4.0000 & .00000 & & & \\
\hline \multirow[t]{2}{*}{8} & Sub-group & 46 & 3.2174 & .96409 & -5.506 & 90 & $\mathrm{p}<.001$ \\
\hline & Upper-group & 46 & 4.0000 & .00000 & & & \\
\hline \multirow[t]{2}{*}{9} & Sub-group & 46 & 2.8913 & 1.23339 & -6.097 & 90 & $\mathrm{p}<.001$ \\
\hline & Upper-group & 46 & 4.0000 & .00000 & & & \\
\hline \multirow[t]{2}{*}{10} & Sub-group & 46 & 3.1522 & .84241 & -6.826 & 90 & $\mathrm{p}<.001$ \\
\hline & Upper-group & 46 & 4.0000 & .00000 & & & \\
\hline \multirow[t]{2}{*}{11} & Sub-group & 46 & 3.4783 & .75241 & -4.703 & 90 & $\mathrm{p}<.001$ \\
\hline & Upper-group & 46 & 4.0000 & .00000 & & & \\
\hline \multirow[t]{2}{*}{12} & Sub-group & 46 & 3.4130 & .77678 & -5.125 & 90 & $\mathrm{p}<.001$ \\
\hline & Upper-group & 46 & 4.0000 & .00000 & & & \\
\hline \multirow[t]{2}{*}{13} & Sub-group & 46 & 3.4565 & .78050 & -4.455 & 90 & $\mathrm{p}<.001$ \\
\hline & Upper-group & 46 & 4.0000 & .00000 & & & \\
\hline \multirow[t]{2}{*}{14} & Sub-group & 46 & 3.3043 & 1.02999 & -4.393 & 90 & $\mathrm{p}<.001$ \\
\hline & Upper-group & 46 & 4.0000 & .00000 & & & \\
\hline \multirow[t]{2}{*}{15} & Sub-group & 46 & 3.1087 & 1.19682 & -5.051 & 90 & $\mathrm{p}<.001$ \\
\hline & Upper-group & 46 & 4.0000 & .00000 & & & \\
\hline
\end{tabular}

Table 6. Descriptive statistics of children's CATES-PV Turkish Version scores according to their genders

\begin{tabular}{lccc}
\hline Gender & $\mathrm{N}$ & $\bar{\chi}$ & $\mathrm{S}$ \\
\hline Girls & & 55.8608 & 4.81114 \\
Boys & 92 & 54.8613 & 4.55119 \\
Total & 171 & 55.3392 & 4.68435 \\
\hline
\end{tabular}


Table 7. ANOVA results demonstrating children's CATES-PV Turkish Version scores according to their genders

\begin{tabular}{lccccc}
\hline Source of Variance & Sum of Square & sd & Mean Square & F & p \\
\hline Between Groups & 39.946 & 1 & 39.946 & .1 .829 & .178 \\
Within Groups & 3690.381 & 169 & 21.837 & & \\
Total & 3730.327 & 170 & & & \\
\hline
\end{tabular}

Table 8. Descriptive statistics of children's CATES-PV Turkish Version scores according to their ages

\begin{tabular}{lccc}
\hline Age & $\mathrm{N}$ & $\chi$ & $\mathrm{S}$ \\
\hline 5 years old & 72 & 51.0556 & 4.09014 \\
6 years old & 99 & 58.4545 & 1.63053 \\
Total & 171 & 55.3392 & 4.68435 \\
\hline
\end{tabular}

Table 9. ANOVA results demonstrating children's CATES-PV Turkish Version scores according to their genders

\begin{tabular}{lccccc}
\hline & & & & & \\
Source of Variance & Sum of Square & sd & Mean Square & F & p \\
\hline Between Groups & 2282.004 & 1 & 2282.004 & 266.279 & .000 \\
Within Groups & 1448.423 & 169 & 8.570 & & \\
Total & 3730.327 & 170 & & & \\
\hline
\end{tabular}

Table 10. Descriptive statistics findings of CATES-PV Turkish Version scores of 5-6 years old children according to the socio-economic levels of their families

\begin{tabular}{lccc}
\hline Socio-Economic Levels & $\mathrm{N}$ & $\chi$ & $\mathrm{S}$ \\
\hline Low & 78 & 53.5897 & 5.47352 \\
Middle & 41 & 55.3415 & 3.63737 \\
High & 52 & 57.9615 & 2.41695 \\
Total & 171 & 55.3392 & 4.68435 \\
\hline
\end{tabular}

Table 11. ANOVA results demonstrating CATES-PV Turkish Version scores of 5-6 years old children according to the socio-economic levels of their families

\begin{tabular}{lccccc}
\hline & Sum of Square & & & & \\
Source of Variance & & sd & Mean Square & $F$ & p \\
\hline Between Groups & 596.313 & 2 & 298.157 & 15.938 & .000 \\
Within Groups & 3134.014 & 168 & 18.655 & & \\
Total & 3730.327 & 170 & & & \\
\hline
\end{tabular}

Table 12. Post Hoc Scheffe Test results conducted after ANOVA to determine between which sub-groups CATES-PV Turkish Version scores differed according to the socio-economic levels of the families

\begin{tabular}{lllll}
\hline \multicolumn{2}{l}{ Socio-Economic Levels (SEL) } & $\chi$ & $\mathrm{S}$ & $\mathrm{p}$ \\
& & & & \\
\multirow{2}{*}{ Low SEL } & Middle SEL & -1.75172 & 83.316 & .113 \\
& High SEL & $-4.37179^{*}$ & 77.325 & .000 \\
Middle SEL & Low SEL & -1.75172 & 83.316 & .113 \\
& High SEL & $-2.62008^{*}$ & 90.208 & .016 \\
High SEL & Low SEL & $-4.37179^{*}$ & 77.325 & .000 \\
& Middle SEL & $-2.62008^{*}$ & 90.208 & .016 \\
\hline
\end{tabular}

$* \mathrm{p}<0.05$ 